Wacquant, L. (2005), Urban outcasts: toward a sociology of advanced marginality. Cambridge: Polity Press.

Wessel, T. (2000a), Social polarisation and socioeconomic segregation in a welfare state: the case of Oslo, Urban Studies 37 (11): 1947-1967.

Wessel, T. (2000b), Losing control? Inequality and social divisions in Oslo, European Planning Studies 9: 889-906.

White, P. (1987), The migrant experience in Paris, in G. Glebe \& J. O'Loughlin (eds), Foreign Minorities in continental European cities, 184-198. Stuttgart: Franz Steiner Verlag.

Wiley, N. F. (1967), The ethnic mobility trap and stratification theory. Social Problems, 15, $147-159$.

Wilson, K. L., \& A. Portes (1980), Immigrant enclaves: An analysis of the labor market experiences of Cubans in Miami. American Journal of Sociology, 86: 295-319.

Yinger, J. (1995), Closed Doors, Opportunities Lost: The Continuing Costs of Housing Discrimination. New York: Russell Sage Foundation.

Zincone, G. \& T. Caponio (2005), The multilevel governance of migration, State of the art report Cluster C9, presented to the first IMISCOE general conference held in Coimbra, 3rd4th December 2004 by Zincone, Caponio and Di Gregorio.

\title{
9 Appendix: Important housing projects funded by the EU
}

The DG Research, the DG Justice and Home Affairs and the DG Employment and Social Affairs funded projects and commissioned studies relevant for the issue of housing and migrant integration.

\section{$9.1 D G$ Research}

The DG Research funded several research projects in the field of housing and integration through its Framework Programmes. The first EU Framework Programme covering research of social and economic issues has been the $4^{\text {th }}$ FWP $(1994-1998)$. Relevant projects funded from the Framework Programmes have been:

URBEX: The Spatial Dimensions of Urban Social Exclusion and Integration (4th FWP, 1999-2002). The study researched strategies and trajectories of socially excluded people in their neighbourhoods and the urban context. Case studies of the project included Amsterdam, Antwerp, Berlin, Birmingham, Bruxelles, Hamburg, London, Milano, Napoli, Paris and Rotterdam. The research project found that "there was strong empirical evidence to suggest that spatial concentration is an important dimension of exclusion and that it adds to the problems and pressures faced by households and communities. However, there also was a need to review and compare this data in relation to different cities and Member States in order to assess the most appropriate 
ways of addressing problems through European, national and local policies" (URBEX Final Report, p. 14). See: http://www2.fmg.uva.nl/urbex/Welcome.html

NEHOM: New Ideas for Neighbourhoods in Europe (4th FWP, 2000-2003). The study evaluates housing and neighbourhood initiatives to improve the quality of life of deprived urban neighbourhoods and to assess their transferability across Europe. Although the project did not explicitly consider migrants, its focus on social exclusion in deprived neighbourhoods implicitly dealt with migrants' integration in the field of housing. The research project published detailed county studies as well as practical recommendations for improvement measures. Case studies of the research project have been Bergen, Berlin, Budapest, London, Malmö, Marseille, Monheim, Napoli, Stockholm, Talinn and Torino. See: http://www.nhh.no/geo/NEHOM/

RESTATE: Restructuring Large Housing Estates in European Cities: Good Practices and New Visions for Sustainable Neighbourhoods and Cities (5th FWP, 20032005). This research project focused on large housing estates built after WW II, usually in the outskirts of larger cities. Although it did not consider explicitly migrants' integration either, the projects findings are also relevant. Case studies have been implemented in Amsterdam, Barcelona, Berlin, Birmingham, Budapest, Jonköping, Koper, Ljubljana, London, Lyon, Madrid, Milano, Stockholm and Utrecht. See: http://restate.geog.uu.nl/

RELAy: Research for Local Action towards Sustainable Human Settlements (6th FWP, 2005-2006, Coordinated Action). This project has been implemented in the context of the UN-HABITAT process and organized the Nanning International Conference on Urban Sustainable Development. Although the broad scope of the urban sustainable development approach of the project did consider housing and migrants' integration only to a small extent, the project's recommendations for "bridging the gap between research and action" (ETH Zurich, 2006) are relevant for the CLIP project's approach. See: http://www.iclei-europe.org/index.php?id=1706

UrbEUROPE: Urban Europe Between Identity and Change (ongoing). This project is a Research and Training Network funded by the EU Commission which focuses on three areas of research: Theoretical analysis of conceptualization and methodology of research on global changes and local impacts, an analysis of how changes impacted on the built environment (gentrification, sub-urbanization and segregation), and an analysis of how the changes impacted on the role of local social policies and governance. The network aims at analyzing existing research on a comparative level as well as filling research gap by new comparative research. It offers training provisions such as fellowships and summer schools. See: http://www.urban-europe.net/

\subsection{DG Justice and Home Affairs}

The DG Justice and Home Affairs became mainly responsible for EU policies for the integration of migrants. Within this scope, the DG JHA (now DG Justice, Freedom 
and Security) funded several studies and projects which also dealt with housing and its role for the migrants' integration.

Benchmarking in Immigrant Integration: The 2003 study compiled by Han Entzinger and Renske Biezeveld provided an overview on the concept of integration, integration policies in Europe, potential indicators for the state of integration within four main dimensions and a discussion of benchmarking based on such indicators. The study also considered housing of migrants as a relevant aspect of general integration policies.

INTI-Programme on the Integration of Third-Country Nationals: Since 2003, the DG JHA supported a number of projects on integration measures for non-EU citizens in Europe which are co-funded $(50 \%)$ by the Commission. Although housing is not a topic of the calls for proposals, one of the projects deals also with housing; "2004/INTI/002: Technical seminars on integration" provides seminars contributing to the second edition of the Commissions Handbook on Integration, which also deals with housing and urban issues among other topics. See:

http://ec.europa.eu/justice_home/funding/inti/funding_inti_en.htm

Handbook on Integration: The first edition (2004) of the handbook on integration compiled by Jan Niessen and Yongmi Schibel mentions housing as a factor for migrants' integration at several occasions. It briefly presents some cases related to housing, namely the Territorial Immigration Council of Belluno (Italy) which promoted a reception and housing programme for labourers with third-country nationality, several German integration programmes for ethnic Germans who receive services for their housing needs, and the Dutch FORUM which initiated foreign residents' planning shops also for housing issues. The second edition of the handbook expected for 2006 will also address issues related to housing and urban issues.

European Migration Network (EMN): The European Migration Network (EMN) was set up, as a pilot project, by the Commission in 2002 under the responsibility of the Directorate General for Justice, Freedom and Security and, since 2003, as a preparatory project which lasted until the end of 2006. The objective of the EMN was to improve the availability of and access to information concerning migration and asylum at European and Member State level in order to support policy- and decision-making in the EU. The network consists of National Contact Points (NCPs) that have been designated by the Member States, each of whom are in turn also involved in the development of a national network. In 2005 the EMN conducted a pilot research study on the impact of immigration onto the European societies. The summary of the national studies identified nine factors, the fourth being housing. In this regard, the summary mentions segregation of migrants and/or low-income classes and the special needs of specific migrant groups such as asylum seekers and refugees (An introduction to the Country Reports on the Impact of Immigration on Europe's Societies, October 2005, p. 16). 


\subsection{DG Employment and Social Affairs}

The DG Employment and Social Affairs funded a series of small studies on discrimination in the area of housing by the national focal points of the RAXEN network at the European Monitoring Centre on Racism and Xenophobia (EUMC), contributing to a summarizing study. It also commissioned a major study in the field of housing and integration.

RAXEN Housing Report: In December 2005 the EUMC published a report titled "Migrants, Minorities and Housing: Exclusion and Discrimination and Anti-Discrimination in 15 Members States of the European Union". The report is based on several country reports from the RAXEN network and gives an overview of these national reports based on data about housing conditions and discrimination as well as on legal provisions and good practices within the old $15 \mathrm{EU}$ members states. It further analyzes the theoretical and methodological approaches employed in the 15 country reports, discusses the relation between integration, segregation and the role of the neighbourhoods and concludes by recommending options for policy and research in the field of housing and migrant integration. (See:

http://eumc.europa.eu/eumc/material/pub/comparativestudy/CS-Housing-en.pdf)

RAXEN 7 Special Study: The issue of housing has been explicitly included as a separate chapter to the templates of the EUMC RAXEN 7 Special Study on "Combating Ethnic and Racial Discrimination and Promoting Equality". The studies which are not published yet by the EUMC report on trends and developments in the period 2000-2006 and will include the new EU 25 member states. The issue of housing is discussed in chapter 3 of the studies, providing national data on housing conditions and patterns of segregation, developments in policy measures on housing exclusion and discrimination, changes in significant good practices and a discussion on the driving forces for the reported developments (EU, national or local policy).

Policy measures to ensure access to decent housing for migrants and ethnic minorities: The DG Employment and Social Affairs commissioned a study on housing policies in eight European countries (Belgium, France, Hungary, Romania, Slovenia, Spain, Sweden and United Kingdom, implemented 2004-2005). The study employed research teams from each country and reported on the national housing frameworks (markets and policies) as well as the migrant and ethnic minority population's situation regarding the housing markets and housing policy measures. It aimed to evaluate these policies in the eight countries and concluded by presenting recommendations for housing policies. Although the study deals explicitly with the housing situation of migrants and ethnic minorities, especially Sinti and Roma, it focuses on the national and EU level, dealing with the local level only peripherally. See:

http://ec.europa.eu/employment_social/social_inclusion/docs/decenthousing_en.pdf

European Regional Development Funds: URBACT

URBACT is a programme under the umbrella of the URBAN II Community Initiative. It has been started by the French Ministry for Urban Policy which coordinates the 
programme. The programme aims to complement the URBAN II activities as well as facilitate the transition from URBAN I to URBAN II programmes. The URBACT programme supports projects in the three activity areas, namely thematic networks, qualification initiatives and studies and dealing with social exclusion at the urban level. The aim is to develop the trans-national exchange of experience between actors, (cities or other local partners as well as participating Member States) in the field of cities and social cohesion. This also covers measures for the inclusion of populations of foreign origin as well as physical regeneration of urban areas. A total of 216 European cities currently participate in the various URBACT activities (see: http://urbact.eu).

Two URBACT projects are of some relevance for the CLIP project. REGENERA is a URBACT network for the exchange of experience on urban regeneration (20042006). Participating cities are Berlin, Belfast, Birmingham, Budapest, Glasgow, Greater Lyon (leading partner), Milano, Praha 8, Saint Etienne, Sant Adria de Besos and Torino.

ECO-FIN-NET is a URBACT network on local economy in disadvantaged neighbourhoods (2004-2006). It aims to develop new ways of fostering local economy in disadvantaged neighbourhoods by innovative financial measures, especially for small and medium sized enterprises (SME). Participating cities are Birmingham, Evosmos, Gdansk, Gera, Gijon, Grenoble, Leipzig (coordinator), Marseille, Rotterdam, Venice, Vienna, Vilnius and West Athens. The German Association for Housing, Urban and Spatial Development (Deutscher Verband, DV) is also participating as a project partner (see: http://urbact.eu/en/ecofinnet/index/). 